\title{
Virginia Woolf ve James Joyce'un Modern Anlatım Teknikleri Üzerine Karşılaştırmalı Bir Çalışma
}

\author{
Sümeyra BURAN ${ }^{1}$
}

$\ddot{O} z$

Yirminci yüzyllın başlarında, modernist yazarlar gerçekliğin geleneksel ifade biçiminden uzaklaşarak yeni deneysel anlatım teknikleri ile karakterlerin iç dünyalarına ve içsel düşünce akışlarına yönelmişlerdir. Modern İngiliz edebiyatında kullanılan anlatım teknikleri yazarlar tarafından hem benzer hem de farklı biçimlerde sunulmaktadır ve bu da her yazara özgün yazım teknik ve yöntemi kazandırmaktadır. Karşılaştırmalı yöntem kullanan bu çalışma modern romanın en önemli iki özgün yazarı olan Woolf ve Joyce'un romanlarını kullandıkları anlatım teknikleri türleri açısından inceleyerek bir sentez sunmaktadır. Woolf un duyarlı, döngüsel ve sarmal anlatımı ile Joyce'un sınırlı noktalama işaretleriyle, rasyonel, doğrusal ve sinematik anlatımı bu ayrıma birer örnektir. Ayrıca Woolf un varolma anlatı tekniği Joyce'un epifan tekniği ile hem benzeşir hem de ayrışır. Her iki yazar da farklı üslup, biçem ve yöntem aracılığıyla tıpkı bir nehir gibi akışkan olan zamanda ileri ve geri giderek tek bir güne sı̆̆an anlatıları ile karakterlerin ruhsal deneyimlerini, duygu ve bilinç akışlarını ortaya çıkartırlar. Bu bağlamda bu makale modern İngiliz edebiyatında bilinç akışı, iç monolog, serbest dolaylı söylem, epifan, varolma anları gibi modern anlatım tekniklerini ustaca kullanan iki öncü yazar olan Virginia Woolf ve James Joyce'un yazı tekniklerindeki benzerlikler ve farklılıkları karşılaştırmayı amaçlar.

Anahtar Kelimeler: Modern Anlatım Teknikleri, Bilinç Akışı, İç Monolog, Epifan, Varolma Anları, Virginia Woolf ve James Joyce.

\section{A Comparative Study on the Narrative Techniques of Virginia Woolf and James Joyce}

\section{Abstract}

At the beginning of the twentieth century, modernist writers moved away from the traditional expression of reality and explored the inner worlds and inner thought flows of characters with new experimental narrative techniques. Authors used either similar or distinct forms of narrative techniques in modern English literature, which attribute them unique writing techniques and styles. This study, using a comparative method, presents a synthesis by examining the novels of Woolf and Joyce, the two most important authors of the modern novel, in terms of different types of narrative techniques they use. Woolf's sensitive, cyclical, and spiral narrative and Joyce's rational, direct, and cinematic narration with limited punctuation marks are examples of this distinction. In addition, Woolf's moments of being and Joyce's epiphany both resemble and differ. Both authors reveal the spiritual experiences, the stream of consciousness, and inner thoughts of the characters in a single day, going back and forth in a fluid time just like a river through different narrative styles and methods. In this context, this article aims to compare the similarities and differences in the writing styles of Virginia Woolf and James Joyce, two pioneering writers skillfully using modern narrative techniques such as the stream of consciousness, interior monologue, free indirect speech, epiphany, and moments of being in modern English literature.

Key Words: Modern Narrative Techniques, Stream of Consciousness, Interior Monologue, Epiphany, Moments of Being, Virginia Woolf and James Joyce

Atıf İçin / Please Cite As:

Buran, S. (2021). Virginia Woolf ve James Joyce’un modern anlatım teknikleri üzerine karşılaştırmalı bir çalışma. Manas Sosyal Arastırmalar Dergisi, 10(1), 27-43.

Geliş Tarihi / Received Date: 21.10.2020

Kabul Tarihi / Accepted Date: 22.11.2020

\footnotetext{
${ }^{1}$ Kaliforniya Üniversitesi Riverside (Misafir Öğretim Üyesi), sburanut@ucr.edu - İstanbul Medeniyet Üniversitesi (Öğretim Üyesi), sumeyra19@hotmail.com, ORCID: 0000-0003-3273-8125
} 


\title{
Giriş
}

İngiliz edebiyatında modernist dönemin başlangıcı Kraliçe Victoria’nın ölümü ve I. Dünya Savaşına ve hatta Malcolm Bradbury'nin Modernism (1991) adlı çalışmasında da dediği gibi 1890’lara kadar dayanır. Bu döneme savaș deneyiminin izleri, yazılı edebiyatta da yenilik ve deneysellik damgasını vurmuștur. "Modern zamanlar ve modern fikirler, yeni biçimler ve yeni edebi tekniklere gereksinim duymuştur" (Parsons, 2007, s. 53). 20. yüzyılın başlarında geleneksel romana hem yapı hem de içerik açısından başkaldırı olarak ortaya çıkan İngiliz edebi modernizm geleneği, gerçeği olduğu gibi resmetmek yerine karakterlerin içsel düşünce ve duygularına önem veren yeni anlatı yöntemleri ve tekniklerini kullanan James Joyce ve Virginia Woolf gibi modernizmin öncü romanciları ile öne çıkmışır. Woolf ve Joyce diğer modernist yazarlarla birlikte yeni öznel gerçekliğin öncüleri olarak içe dönük bilincin ve anlık düşüncelerin açığa vurumu olan bilinç akış1 (stream of conscioussness), iç monolog (interior monologue), serbest dolaylı anlatım (free indirect speech), epifan (epiphany) ve varolma anları (moments of being) gibi spiral anlatım teknikleri veya sinematik anlatım tekniklerini kullanmışlardır. Ancak, karakterlerin bilinciyle düşünce ve duygu akışlarını yansıtan bu iki yazarın modern anlatım teknikleri arasında bazı benzerlikler ve farklılıklar vardır. Bu çalışma, Virginia Woolf ve James Joyce'un romanlarında kullandıkları modern anlatım teknikleri ve tarzlarını karşıslaştırmaktır.

Her yazarın kullandığı anlatım tekniğinin diğerinden ayıran özelliklerin çeşitliliği nedeniyle, modernist romanın bir dizi standart özelliğini vermek zordur. Ancak, genel olarak dil, olay örgüsü, temalar, zaman, yer ve karakterlerle birçok deneysel ve yenilikçi girişim gerçekleşmiştir. Her yazarın kendine özgü bir toplum algisı ve onu kendi perspektifinden yansıtma biçimi vardır; örneğin Virginia Woolf Bayan Dalloway (Mrs. Dalloway, 1925) ve Deniz Feneri (To the Lighthouse, 1927) romanlarında ve Kendine Ait Bir Oda (A Room for One's Own, 1929) yazısında feminist bir bakış açısına sahiptir. Ancak James Joyce'un Sanaţ̧ınn Bir Genç Adam Olarak Portresi (A Portrait of an Artist as a Young Man, 1916)'sinde psikolojik bir bakış açısı vardır. Ortak paydada buluştukları nokta, çoğu modernist yazarın, öz-bilinçli bir şekilde 19. yüzyıl geleneksel sosyal düzenine, sosyal geleneğine, bakış açısına, rasyonalizme ve gerçekçilik ideolojisine karşı bir başkaldırı göstermeleridir. Kısaca, David Lodge modernist romanı şöyle özetler:

\begin{abstract}
Modernist roman insan beyninin bilinci ve ayn zamanda bilinçalt ve bilinçdşs çalışmalarylla ilgilenir. [...]

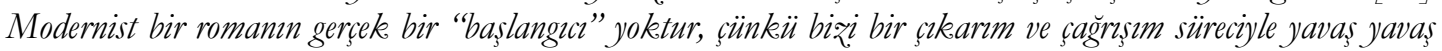
kendimize așina bale getirdigumiz akan bir deneyim akışna sürükler ve sonu, okuyucu karakterlerin son kaderi konusunda sü̈heye düsürrecek sekeilde genellikle "açı." veya belirsizdir. [...] Modernist kurgu, malzemesinin düz kronolojik siralanmasindan ve güvenilir, her șeyi bilen ve müdahaleci bir anlaticmin kullanmmindan kaçinr.

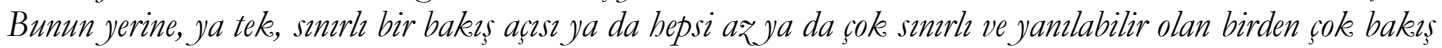
açısı yöntemini kullanı: ve eylemin kronolojik arahğg boyunca ileri ve geri çok fą̧la çapraz referans içeren, akicı ya da karmaşı bir zaman işleme eğilimindedir (1977, s. 45-46).
\end{abstract}

İlk dalga modernist yazarlardan sayllan John Galsworthy, H.G. Wells, Arnold Bennett, E. M. Forster ve Joseph Conrad yenilikçi yöntemleri izlemişlerdir. Onlara, romanlarındaki iç benliğin denemeleri ve incelemeleriyle Dorothy Richardson, Virginia Woolf ve James Joyce gibi kullandıkları anlatım teknikleri ile kurguya büyük yenilik katan ikinci bir dalga katılmıştır (Holman ve Thrall, 1985, s. 275). Woolf un "Modern Romanlar" adlı makalesi (1919), H. G. Wells, Arnold Bennett, John Galsworthy ve Hugh Walpole gibi içsel bilinç deneyimini benimsemeyen Edward dönemi romancıları ile "modernlerin yeni spiritüalist odağını" temsil eden ruhsal zihin ya da bilinç deneyimine daha fazla önem veren Joyce, T. S. Eliot, E. M. Forster ve Lytton Strachey gibi yazarların maddeci anlatıları arasındaki fark1 ortaya koyar (Parsons, 2007, s. 15). Bu ikinci dalga yazarlar modernizmin ilkesi haline gelen Ezra Pound'un "Yeni Yap!" sloganı doğrultusunda yenilikçi bakış açısı ile bilinç akışı gibi yeni deneysel yazım teknikleri kullanarak neredeyse kutsal bir zorunluluk ilkesi edinmişlerdir (Gay, 2008, s. 106). 19. yüzyılın sonralarında ve 20. yüzyılın başlarında başat olan ve insanların iç dünya gerçeklerine kapı açan psikanaliz bilinç akışı, iç monolog gibi modernist anlatım tekniklerinin gelişmesine zemin hazırlamışır. Hiç şüphesiz "yeni yap" düşünce akımı da bu gelişmeler arasında etkili olmuştur. Woolf, modern yazarların stratejisini şu şekilde özetler:

Hayat böyle midir? Romanlar böyle mi olmalıdır? Kendi içinize bakın, göreceksiniz ki, hayat "böyle" olmaktan cok uzaktır. Siradan bir zibni, siradan bir günü ele alın. Zibin, önemsiz, fantastik, gelip geçici veya çeliğin keskinliguyle kazınmıs sayısız izlenim alır. Bu iəlenimler her taraftan üzerimize, sayısız atomdan olusan ardı arası kesilmeyen bir sağanak gelir ve bu atomlar üzerimize boșandıkça Pazartesi veya Salı hayatına dönüstürdükeçe, temelde eskisinden büsbütün ayrlır [...] Hayat simetrik bir biçimde düzenlenmiş bir dizi gösterilambası değildir; yaşam tüm bilincimiz̨in bașından sonuna kadar bizi sarı kusatan yar saydam bir zarf olan ışıkl bir haledir. Romancınn görevi ne denli sapkınlık ne denli karmaşıklık gösterirse göstersin, bu değişken, bu 
bilinemeyen, bu başıbos rubu, mümkün olduğunca, azyabanc ve disssal karışımla iletmek değil midir? (Woolf, 1953, s. 256).

Modernist romanın önceki edebi hareket olan ve insan deneyiminin doğrudan temsilini yansıtan realizm "anlayışından farklılık gösterir” ve "bu deneyimi nesnel olarak iletme olasılığına şüpheyle yaklaşır; bu nedenle okuyucuya karakter, zaman ve yer hakkında açıklayıcı veya 'dış' ayrıntılar sağlama yükümlülügünü reddeder” (Parsons, 2007, s. 53). Modernist romancılar daha çok yaşamın ruhsal kalitesiyle ya da akıl ve bilinçle ilgileniyorlardı ve bu ikinci dalga yazarlar rasyonel düşünce görüşüne karşıydı. Dolayısıyla, Richardson, Woolf ve Joyce’un “bir karakterin sosyal gelişiminin geleneksel temsili ile kendi bireysel psikolojik var olmasını; sahnenin dış tasviri ile bilincin içsel açı̆̆a vurulma tasvirini ve kronolojik anlatı ve dramatik olay örgüsü ile zihinsel yaşamı oluşturan anlık düşünce ve izlenimlerin akışını değiş tokuş eden” yeni öznel gerçekçiliğin öncülerinden bazıları olduğu söylenebilir (Parsons, 2007, s. 53). Modernist romanın tanımlayıc1 özelliklerinden biri de bilinç akışı tekniğidir. Modernist sanatçılar bilinç, zaman ve bilginin doğası ile ilgilenmişlerdir.

\section{Bilinç Akışı}

Chris Baldick bilinç akışı yöntemini “insan zihninde duyuların, algının, düşüncelerin, duyguların ve hatıraların sürekli akışı veya zihinsel süreçlerin kurgusal karakterlerle harmanlanması gibi edebi bir metot" olarak tanımlamaktadır (2001, s. 212). Aslında 18. yüzyılda Laurence Sterne'nin Tristram Shandy (1757) adlı psikolojik romanında (Cuddon, 2013, s. 683), 19. yüzyılda Edgar Allan Poe'nun "Gammaz Yürek" ("The Tell-Tale Heart," 1843) adlı kısa öyküsünde de (Pugh and Johnson, 2014, s. 143) veya Henry James'in Bir Hanımefendinin Portresi (Portrait of a Lady, 1881) adlı romanında (Abrams 299) bilinç akış1 tekniğinin izleri olduğu görülmektedir. Ancak bu yöntem tam olarak 20. yüzyll modernist edebiyatında tamamen gelişmiş ve kullanılmıştır. Bilinç akışı terimi edebiyatta ilk olarak 1918 yılında May Sinclair tarafindan Dorothy Richardson'un Hac (Pilgramage, 1915) eserine yaptı̆̆1 eleştirileri esnasında kullanılmıştır (Stevenson, 1992, s. 41). Dolayısıyla, bilinç akışı tekniği tam manasıyla ilk olarak Richardson öncülügünde kullanılmıştır. Daha sonra James Joyce, Virginia Woolf ve William Faulkner gibi yazarlar tarafindan kullanılmaya devam etmiştir. Slyvia Plath ve Samuel Beckett, Terry McMilllan ve Irvine Welsh gibi postmodernist yazarlar tarafindan ve halen günümüz edebiyatında da kullanılmaya devam etmektedir.

Modernist dönemin üç temel felsefi düşüncesi bu bilinç akışı ile ilgili yeni tekniğin gelişmesine zemin hazırlamıştır: Bergsonizm, faydacılık (pragmatizm) ve görüngübilim (fenomenoloji). Bu felsefi düşünceler insan bilincinin dünyayı doğrudan nasıl deneyimlediği ile ilgilenirler. Henri Bergson, Time and Free Will: An Essay on the Immediate Data of Consciousness olarak Ingilizce'ye çevrilen Essai sur les données immédiates de la conscience (Zaman ve Özgür İrade: Bilincin Anlı. Verileri Üzerine Bir Deneme, 1889) çalışmasında içsel deneyimler felsefesine odaklanır. Zamanı süre olarak tanımlayan Bergson'un hayatın sürmekte olan bir akış olduğu felsefesi, modernist romanda da zamanın akışkan olduğu ve kronolojik bir zamanı kapsamadığ1 ve dolayısıyla da zihnin de akış süreci içinde olduğu yönünde modernist tekniklere zemin hazırlamıştır. Psikolog ve düşünür William James ${ }^{2}$, faydacı, ampirik olarak altını çizdiği felsefesine radikal deneycilik adını verir. James Psikolojinin Illkeleri (Principles of Psychology, 1890) çalışmasında bilinç deneyimini sürekli bir şey olarak tanımlar; “Eklemli bir şey değil; akar. Bir 'nehir' veya 'akarsu', en doğal olarak tanımlandığı metaforlardır. Bundan sonra ondan söz ederken, ona düşünce akışı, bilinç akışı veya öznel yaşam diyelim” (1950, s. 239). Yani, bilincin tren veya zincir gibi eklemli bir bağ olmadığ1 aksine tıpkı bir nehrin akışı gibi süreklilik halinde olduğunu savunur ve böylece bilinç akışı asla bitmez. Aslında eleştirmen George Henry Lewes ünlü Alman fizikçi Fencher'den etkilenerek "Yaşam ve Zihin Sorunlar" ("Problems of Life and Mind") makalesinde bilinç akışını daha önce kullanmıştır. Leves insan zihninin sürekli olarak farklı uyarma seviyeleri arasında değiştiğini açıklar: "bu nedenle Bilinç akışı uyarılma akışından oluşur ve bu akışın dalgaları ve dip yoğunlaşma dalgası vardır: eğriler süreklidir ve fark edilmeden karışır; kırılma veya duraklama yoktur” (akt. Holland, 1986, s. 36).

Martin Heidegger'in görüngübilimi ise Kartezyen felsefede benlik ve dünyanın radikal ayrımına karşı varolma felsefesine eğilir (1962, s. 149). Heidegger, otantik ve özgün olmayan birliktelik tarzlarına odaklanırken, modernist romancılar, bireylerin içinde yaşadıkları daha geniş dünyayı nasıl deneyimlediklerine odaklanır. Klasik realist anlatım tekniği karakterin bilincine doğrudan birinci şahıs anlatı olarak yer verir çünkü tüm bilincin benzer mantık ve diş yönelim niteliklerine sahip olduğunu benimser. E. M. Forster realizmden modernizme geçiş anlatısı sunarak okuyuculara psişik içselliğe bir bakış sağlar. Ancak Forster, bu

\footnotetext{
${ }^{2}$ Ünlü yazar Henry James’in erkek kardeşidir.
} 
içsel bakış açısını gösterirken okuyucuları hala dışarıda tutar (Kern, 2011, s. 83). Daha sonra gelen modernist yazarlar ise içselliği serbest dolaylı söylem ve bilinç akışı gibi yeni modernist anlatım teknikleri ile dile getirirler. Kronolojik zamanı kırarak geriye dönüş ve ileriye gidiş yöntemleri ile karakterlerin bilinçaltına inerek Joyce (Ulysses romaninda) veya Woolf (Bayan Dalloway romaninda) gibi modernist yazarlar sadece tek bir günü anlatan romanlarda bile karakterlerin içsel gerçeklerini anlatabilmişlerdir.

Psikanalizin kurucusu Sigmund Freud da Rüyalarn Yorumu (The Interpretation of Dreams, 1899) kitabinda rüyaların yorumu üzerinden bilinci bir akış olarak değerlendirir. Bilinçdışının ruhsal dünyamıza ve gerçekliğimize ulaşmada önemli rol oynadığı düşünen Freud bilinçdışımızın bilinçlilik evrenini kapsadığını ve bu yüzden tıpkı dış dünya gibi bilinmezliklerle dolu olan bilinçdışımızın keşfedilmesinin zor olduğundan ve bilinçsiz kategoriye giren rüyalarda sansürsüzce dışa vurulabileceğinden bahseder (1965, s. 632). Aynı şekilde okuyucu da karakterin sansürsüz bilinç akışındaki noktalama, bağlaç ve ifade eksikliklerini yorumlayarak keşfeder. Carl Gustav Jung da Bilinçdssımmn Psikolojisi (Psychology of Unconscious, 1912) kitabında kolektif bilinçdışı ile bilinç akışının ortak düzlemini ortaya koyarak kontrollü ve rüya (hayal) düşünceleri olarak iki tür düşünme şeklinden bahseder. Jung da Freud'un bilinçdışı rüya teorisinden yola çıkarak kişinin kendi kişisel bilinçdışının tüm insan ırkının geçmiş birikimlerinden mit ve arketipleri barındıran kolektif bilinçdışı aracılı̆̆yla etkilendiğini savunur (1949, ss. 21-22). Kısacası, Freud'un teorileri altında 20. yüzyllın ilk yarısında birçok modernist yazar yeni yazma tekniği olan bilinç akışı tekniğini benimsemişlerdir (Liu 1993).

George Lukacs’a göre "bilinç akışı tekniği sadece salt biçimsel bir anlatım tekniği değildir; anlatı dokusunu ve karakterin sunuluşunu sağlayan biçimlendirici ilkenin ta kendisidir" (1963, s. 18). Modernistler ayrıca "anıları, beklentileri, duyguları, yargıları, fantezileri, beş duyudan gelen uyaranları ve hisleri, kulak misafiri olan veya hatırlanan konuşma parçalarını, sözdizimi parçalarını, hatta kelimelerin parçalarını veya icat edilen kelimeleri” yani karakterlerin içsel deneyimlerini eşzamanlı olarak karakterlerin zihninin içinden geçirerek bir bilinç akışı oluştururlar (Kern, 2011, s. 87). Bilinç akışı tekniğinde,

[...] karakterin zihninden akip giden düşüncelerde mantıksal bir bağg yoktur. Daba çok çağrrşım ilkesine göre akarlar. Aynca gramer kurallarm da gözetmezler. Bilinç akışında yalmz düsünceler değil duyumlar, imgeler de yer alabilir ve tam bir bilinç akışı tekniğzi ile okura bir sahne gibi sunulan, bilincin en karanlı, bilincin altnna en yakin kesimidir" (Moran, 2003, s. 82).

Woolf, Bayan Dalloway romanı için: "yaptığım keşif hakkında daha epeyce bir şeyler söylemeliyim aslında; kişilerimin artlarında nasıl güzel mağaralar oyduğumu; bunun tam istediğim sonucu verdiğini düşünüyorum: insancillık, mizah, derinlik. Fikir şu, mağaralar birbirine bağlanacaklar ve şu anda birer birer gün ışığına çıkıyorlar" der (1954, s. 59). Woolf un bilinç akışı tekniği ile karakterlerin kazdığı bu tüneller veya mağaralar aracılığıyla kendi içsel deneyimleri, bilinç akışlarının dişa vurumu olarak okurlarla buluşur.

Woolf Bayan Dalloway'de bilinç akışı anlatım tekniği ile Clarissa, Peter ve Septimus'un düşünce, duygu ve anı akışını sunar. Bayan Dalloway'in öyküsü 1923 Haziran ortalarında tek bir gün içinde ve tek bir yerde, Londra'da geçer. Ancak Woolf, bilinç akışı tekniği ile karakterlerin zihninde dolaşarak on sekiz yllı kapsayan zamanı ve Hindistan, Bourton, Londra ve Fransa gibi çeşitli yerleri gezerek olayların geçtiği mekânı genişletir. Ayrıca, hikâyenin ortasından başlama tekniğini (In Medias Res) kullanarak hikâyeyi üçüncü şahıs anlatı ile geri dönüşler, iç monolog ve diğer başka zaman genişletme araçları ile anlatıyı ana olayın etrafına inşa eder (Holman ve Thrall, 1985, s. 230). Mrs. Dalloway, tupk1 Joyce'un Uylsses'indeki Bloom ve Stephen gibi iki paralel olay örgüsünde Clarissa Dalloway ve Septimus Smith olmak üzere iki ana kahramanını tek bir güne hapseder. Yüksek sınıf ev hanımı olan Clarissa'nın geçen tek bir gününde parti hazırllğı için çiçek almaya gitmeye başlaması ile tüm bilinç akışı serüveni zamanda bir ileri bir geri akarak orta yerinden başlar ve biter.

\section{İç Monolog}

İç monolog 19. yüzyılın sonlarında Fransa'da modern psikolojinin edebi uygulamalara yansıması olarak ortaya çıkmışır. Bilinç akışı, karakterlerin iradeleri dışında dış olaylara verdikleri içsel tepkilerinin bilinç altlarında psikolojik duygularının dışa vurumu ile ortaya çıkan düşüncelerinin ve hislerinin akışını ifade ettiğgi iç monolog şeklinde görülür. Leon Edel Modern Psikolojik Roman (The Modern Psychological Novel, 1964) çalışmasında bilinç akışı ile iç monoloğu kabaca benzer tür olarak görür ve hatta bu iki tekniğin birbirlerinin yerine bile kullanılabileceğini savunur. Edouard Dujardin iç monolog tekniğini "açıklamalar veya yorumlar aracılığıyla yazar müdahalesi olmaksızın, bize doğrudan karakterin iç dünyasını tanıtmak amacıyla karakterin sahnedeki konuşması" olarak tanımlar ve ayrıca "bilinç dışına en yakın olan en samimi düşüncenin ifade tarzıyla, minimum sözdizimine indirgenmiş doğrudan ifade biçimiyle" geleneksel monologdan ayrıldığını 
ifade eder (Akt: Humphrey, 1954, ss. 58-59). Ancak Dujardin'in bilinç akışı ve iç monoloğun birbirinin yerine geçtiğini gösteren bu tanımlaması birçok eleştirmen tarafından tutarsız bulunur. Bilinç dışına en yakın olan düşüncelerin konuşma yoluyla ifade edilmediği konusunda hem fikir olan eleştirmenler çeşitli bilinç kontrolü ile bilincin geniş zihinsel alanı ifade ettiğini ve konuşmanın basit bir şekilde sadece görüntü ve duyuları alma eyleminden farklı olduğunu savunurlar.

J. A. Cuddon'un da Edebi Terimler ve Edebi Kuram Sö̋zlüğ̈̈nde iç monolog ile bilinç akışı tekniklerini eş anlamlı olarak kabul etmesine rağmen (2013, s. 683), yine de her iki terim birbirlerinden az da olsa ayrışırlar. Concise Oxford Edebi Terimler Sözliuğ̈ de iki terimin tam manasıyla birbirinden psikolojik ve edebi olarak ayırt edilebileceğini öne sürer. "Psikolojik anlamda, bilinç akışı ana fikir, iç monolog ise onu sunma tekniğidir" (Baldick, 2001, s. 212). Diğer bir deyişle, çoğu eleştirmen her iki terimi eş anlamlı olarak kullansa da bazıları iç monoloğu edebi araç olarak düşünerek bilinç akışından ayırırlar. Robert Humphrey (1954), Wayne Booth (1961), Melvin Freidman (1955), Frederick Hoffmann (1945) ve daha birçok yazar bilinç akışının iç monoloğu içeren bir edebi tür olarak belirlenmesi gerektiğini inanırlar. Ancak hem Lawrence Bowling (1950) hem de Erwin Steinberg (1969) bilinç akışının özel bir teknik olduğunu, içsel monologdan farklı olduğunu ve her bir terimin tam olarak tanımlanabileceğini iddia eder (akt. Naremore, 1973, s. 61). ${ }^{3}$ Robert Humphrey aslında bilinç akışının edebi bir teknik olan iç monolog ile karıştırıldığını ve bilinç akışını sunmak için dört tekniğin kullanıldığını savunur: dolaysız iç monolog, dolaylı iç monolog, ilahi (her şeyi bilen yazar tarafindan) betimleme ve kendi kendine konuşma (soliloquy) (1954, ss. 23-24). İç monoloğu karakterin tam bir konuşmaya dökmediği kısmen veya tamamen söyleyemediği iç konuşması olarak tanımlayan Humphrey gibi (1954, s. 24) Randell Stevenson da “bem Dalgalar (The Waves)'de hem de Woolf un yazilarında genel olarak bilinç akışından ziyade iç monoloğun kaydedilen biçem için uygun terim olduğunu düşünür" (1992, s. 57).

Bowling bilinç akışı ve iç monoloğun iki farklı şeyi temsil ettiğini savunur. İç monoloğun sıradan konuşmaya en yakın olan zihin düzeyinde görüldügünü ve "bir karakterin iç dünyasının bilinçdışından en uzaktaki kısmını" tanımladığını söyler. İç monoloğun tamamen zihnin sözel alanında konuşlandığını ve dolayısıyla görüntü ve duyuları çok fazla dahil etmediğini savunur. İç monoloğun yüksek derece gerçeklik olduğunu ve okuyucuyu ikna etmek için de "sıradan konuşmadan daha mantıklı ve resmi" olarak verildiğini söyler (Bowling, 1950, s. 334). Bowling bilinç akışını veya iç monoloğu iç analiz adını verdiği teknik ile karıştırmamak gerektiğini belirtir. İç analizde "yazar bizimle karakterin zihni arasında bir tercüman olarak durur ve karakterin ne düşündüğü hakkında yorumlarını gösterir" (1950, s. 343). Dolayısıyla, iç analiz bize özet geçerken bilinç akışı veya iç monolog bize olayı sahneler, yani Bowling'in kendi ifadesiyle "zihnin dolaysiz alıntısıdır" (1950, s. 345).

Bowling'in sınırlı çözümlemesine karşın Humphrey bilinç akışı ve iç monoloğu oldukça geniş bir çerçevede tanımlar. Humphrey'e göre bu "[i] ki teknik arasındaki temel fark, dolaylı monoloğun okuyucuya yazarın sürekli varlığını hissettirmesidir; oysa doğrudan monolog bunu tamamen veya büyük ölçüde dışlar" (Humphrey, 1954, s. 29). Genel olarak iç monolog dolaylı ve dolaysız olmak üzere iki şekilde kullanılır. Dolaylı iç monologda karakterin bilinç akışı ilahi anlatıcı tarafından ("o düşündü", "o dedi”" şeklinde) üçüncü şahıs anlatı ile doğrudan yazarın müdahalesi eşliğinde okuyucuya sunulurken dolaysız iç monologda yazarın bir müdahalesi ve varlığı olmaksızın genellikle birinci tekil şahıs anlatı ile doğrudan okuyucuya iletilir. Dolayısıyla, eğer bir ayrım yapmak gerekirse iç monolog bilinç akışından bir bilinç akışı tekniği olması yönüyle belki ayrrlabilir ancak genel olarak zaten her ikisi de karakterin iç dünyasina tutulan birer mercektir. Derek Bickerton ise Humphrey'in bilinç akışında tanımladığı tekniklere eleştiri ve karşıllk olarak iç monoloğun dört türünü şu şekilde tanımlar:

İç konuşma, yalnızca sözlü konuşmayı oluşturmak için kullanılan yöntemlerden biri ile oluşturulabilir.

(2a) Kendi kendine konuşma (soliloquy) dolaysız konuşmada kullanılan iç konuşmadır.

(2b) İlahi betimleme dolaylı konuşmada kullanılan iç konuşmadır.

(2c) Dolaylı iç monolog serbest dolaylı konuşmada kullanılan iç konuşmadır.

(2d) Dolaysız iç monolog serbest dolaysız konuşmada kullanılan iç konuşmadır (1954, s. 238).

Birkerton kullanılan eserlerde bu dört türün ikisinin veya üçünün noktalama işaretleri ile aynı paragrafta bile kullanılabileceği gibi dolaysız iç monoloğun ilahi betimlemeye de dönüşebileceğini ancak dolaylı cümlede kendi kendine konuşmanın veya dolaylı iç monoloğun birinci tekil şahıs ile kullanılamayacağını söyler.

\footnotetext{
${ }^{3}$ Bkz. Steinberg (1979).
} 
Joyce'un iç monoloğunun "bir anlatıcının denetimine dair her türlü işaretten" yoksun olduğunu (Lillyman, 1971, s. 47) Joyce’un Ulysses romanındaki şu iç monolog örneği ile açıklayabiliriz:

Dudaklar belirsiz bir sevinçle aralandr. İlk mektubundan bu yana değismiş. Acaba kendisi mi yazmıs? Hiddetlenerek: benim gibi iyi bir aile kiæn, saygudeğer bir şabsiyet. Bir Pazar duasindan sonra bulusabiliri:. Tessekekür ederim: ben almayaym. Tipik aske didismeleri. Ardindan sulh olmąlar. Molly ile atısmalar kadar kötii. Puronun sakinlestirici etkisi var. Narkotik. Bir dahaki sefere daba ileri git. Yaramaz oğlan: cezalandracak: kelimelerden korkuyor, elbette. Biraz hrppala, neden olmasin? Gene de denemeli. Her seferinde azar az̧ar. Cebindeki mektubu parmaklar ile yoklayarak iğneyi kâğtttan çekip çıartt. Alelade bir iğne, ha? İgneyi yola firlattı. Giysilerinin bir yerinden: iğneyle tutturulmus. Kadinlarn kullandiğ iğnelerin sayısı acayip. Dikensiz gül de olmaz (1922, s. 75).

Bu pasajda ilk üç cümlede üçüncü şahıs anlatı ile geçen ilk üç cümleden sonra Bloom’un iç monoloğunu duyarız. Dördüncü cümlede "benim gibi iyi bir aile kızı, saygıdeğer şahsiyet” cümlesinden Bloom'un Martha Clifford'un söylediğini sandığı bu kelimelerin akışına dalarız. Yine Bloom Martha'nın mektubundaki "yaramaz oğlan: cezalandıracak" kelimelerini anımsar ve bu sözlere "kelimelerden korkuyor, elbette" yorumunu yapar. Bloom'un tüm bu iç monologlarında Martha "diyor ki” gibi üçüncü şahsa hitaben bir dolaylı aktarım kelimeleri göremeyiz. Tıpkı bir konuşmaya benzeyen dolaysız doğrudan bir aktarım görürüz. Çıkarılmış özneleri, yardımcı fiilleri geri koyarsak "Martha ilk mektubundan bu yana değişmiş," "Mektubu Martha kendisi mi yazmış?" veya "Martha hiddetleniyor," "Pazar günü birlikte buluşabilirdik" gibi kişiye atfedilen zamirler ile daha anlaşılır olurdu. Cümle ögelerinin eksik olması iç monologlarda konuşma havasını estirmek için sık kullanılan bir durumdur. Ancak kendi kendine konuşmadan (soliloquy) farkı geleneksel dil bilgisi ve söz dizim yoksunluğudur ve böylece Bloom'un purosu gibi yersiz konu dışı eklemlemeler ile akış bozulur (Bickerton, 1967, s. 237).

\section{Serbest Dolaylı Söylem}

Serbest dolaylı söylem (free indirect speech), bilinç akışını göstermenin başka tekniklerinden birisidir. Serbest dolaylı söylem tekniği karakterlerin dolaysız duygu, düşünce ve söylemlerinin anlatıcının dolaysız söylemi ile birleşerek kendi bakış açısından anlatması ile sunulur. ${ }^{4}$ Yani üçüncü şahıs anlatının birinci tekil şahıs bakış açısından istifade etmesi anlamına gelir (Baldick, 2001, s. 102). Serbest dolaylı anlatım her zaman geçmiş zamanda ve üçüncü şahıs anlatım ile sunulur. Bu da serbest dolaylı anlatımı birinci şahıs anlatım ile ifade edilen iç monologdan ayırt eden en temel özelliğidir; örneğin, Woolf un Bayan Dalloway'indeki en güçlü içsel bakış yöntemi, karakterlerin zihninde herhangi bir zamanın koşullarına iliş̧kin kendi bakış açılarını ortaya çıkaran serbest dolaylı söylemlerle meydana gelir. Romanın daha ilk cümlesinden serbest dolaylı söylemler ile Clarissa'nın zihnine dalarız: "Bayan Dalloway çiçekleri kendisinin alacağını söyledi [...] Hem ne güzel bir sabah diye düşündü Clarrisa Dalloway, kumsaldaki çocuklara üleştirilmiş gibi taptaze" (Woolf, 1922, s. 3). Üçüncü şahıs ilahi anlatıcının rehberliği olmaksızın geçmişten şimdiye ve karakterden karaktere bir bilinç akışı aktarmak mümkün olmayacaktı ve bu da iç monolog tekniğinin bir yansıması olarak çıkar karşımıza. Düşünce akışı boyunca bir karakterin zihninden diğerine her geçişte farklı bakış açılarını da yansıtmış olur. Dolayısıyla, odaklama da roman boyunca sürekli değişir ve çeşitli iç odaklama yansıttlır. Aynı zamanda bu örnekte, "Bayan Dalloway dedi" ve "Clarrisa Dalloway düşündü" ifadeleriyle serbest dolaysız aktarım yapılarını görürüz. Peter Verdonk’a göre de romanın bu ilk cümlesi iki taraflı etki yaratan serbest dolaylı söylem tekniği ile hem anlatıcı ile karakter arasında bir mesafe oluşturur hem de karakterin bilincini yansıtarak okuyucuya bir yakınlık duygusu aktarır (2002, s. 52). Okuyucu romana başlar başlamaz Bayan Dalloway'in zihninin akışında buluverir kendini.

\section{WOOLF VE JOYCE'UN KARŞILAŞTIRMALI MODERNİST ANLATIM TEKNİKLERI}

Woolf ve Joyce arasındaki benzerlikleri işleyen birçok araştırma vardır (Jenkins 1988; Pearce 1993; Anspaugh 1994) ve Christopher Ames (1991) ve Jane de Gay (2006) gibi eleştirmenler, iki yazarın eserleri arasında paralellik açısından incelemeler yapmıştır. Modern İngiliz edebiyatında bilinç akışı yönteminin en önemli iki öncüsü olarak sayılan Woolf ve Joyce modern paralel düzlemde yol alsalar da aralarında yazı ve anlatım teknikleri açısından bazı farklılıklar vardır.

\footnotetext{
${ }^{4}$ Dolaysız söylem olan ““yarın burada kalacağım’ diye düşündü” ifadesinin serbest dolaysız söylemde “ertesi gün burada kalacağını düşündü” olarak üçüncü şahıs anlatıcının ağzından anlatılmasıdır.
} 
Modernizm, "ilerlemenin liberal ideolojisine şüpheyle yaklaştı ve zamanla ilgili edebi deneyimleri, bir ilerleme fikri için gerekli olan doğrusal zamansallı̆̆ baltaladı. Geçmişi, düzen ve istikrarın konumu olarak gördü" (Whitworth, 2010, s. 108). Woolf ve Joyce'un her ikisi de "edebi tarih, estetik teori ve sanatsal strateji sorularını eleştirel ve kurgusal yazılarında" genişletmişlerdir ancak Woolf "kendini sıradan okuyucu olarak adlandırdığ1 şeyle özdeşleştirmiştir" (Parsons, 2007, s. 15). Woolfun deneysel yapısı ve bilincin temsili, Joyce'unkine benzer, ancak "dönemin eleştirisinde, Woolf genellikle bir duyarlllık romancisı (novel of sensibility) olarak ve kullanılan övgü terimleri ile- 'ince', 'duyarlı', 'kadınsı' olarak kategorize edilmiştir" (Whitworth, 2010, s. 108). Diğer yandan, Christopher Butler, "Joyce'un modernist fikir iklimine karş1 tavrının büyük ölçüde özünde yalnız (ve egoist) deneyselliğinden çıkarılması gerektiğini” savunur. Örneğin Ulysses'de on sekiz farklı bakış açısı ve birçok üslup kullanır bu yüzden "Biçemsel çeşitlilik, gerçekliğin doğru resmedilmesine karşı esasen göreceli bir tavrı kabul eder” (Butler, 2004, s. 69). Dolayısıyla, Joyce, 19. yüzyıl romanının ideolojik otoritesini reddeder.

Woolf ve Joyce arasındaki en bariz fark, anlatım tarzlarıdır; ilki kadın anlatı biçemini, ikincisi ise erkek anlatı biçemini kullanır. Kadın anlatı biçeminde konu, bakış açısı, cümle yapısı ve dil gibi pek çok değişiklik vardır. Modernist anlatımda kadının sesi olan Woolf, kendilerini farklı ifade eden kadınların iç dünyalarını sergiler ve özgürce yazabilecekleri kendilerine ait bir odası olan kadınların yeni bir anlatı inşa ettiklerini ve bunun da bir kadın anlatısı olduğunu savunur. Kadınlar Viktorya toplumunda ya evdeki bir melek ya da bir canavar olarak görülüyordu (Gilbert ve Gubar, 2000, s. 79), yirminci yüzyıla geldiğimizde ise tavan arasındaki deli bir kadın olarak görüldüler (Buran, 2000). Bu nedenle, feminist söylemin mihenk taşlarından olan Woolf bir kadının kendini özgürce ifade edebilmesi için bir alana veya kendine ait bir odaya sahip olması gerektiğini savunmuştur. Dolayısıyla, Woolf un eserlerini okurken, Joyce'a kıyasla kadının sesini duyuyoruz; örneğin, Bayan Dalloway'de, Bayan Dalloway Sally ile olan ilişkisini "bir elmas, sonsuz derecede değerli bir şey" (Woolf, 1922, ss. 52-53) olarak görmektedir ve şöyle söyler, "bu insanın bir erkek için hissettiği gibi bir şey değildi. Tamamen ilgisizdi ve ayrica bu kadinlar arasinda var olabilecek bir nitelikteydi" (Woolf, 1922, s. 51). Dolayısıyla, Woolfun eserlerinde kadın bakış açısıyla kadınca düşünce ve duyguları görüyoruz. Diğer taraftan, Joyce, Molly'nin son sözleriyle Ulysses'ini bitirdiğinde, Bloom'un evlilik teklifini kabul eden bir kadına son sözleri verir; "ve sonra bana evet dememi istedi, evet dağ çiçeğim ve önce kollarımı ona dolayıp bana doğru aşağı çektim, böylece göğüslerimin tüm kokusunu hissedebilsin evet ve kalbi deli gibi atıordu ve evet ben evet dedim evet kabul ediyorum, Evet" (Joyce, Ulysses, s. 732). Olumlu bir şekilde bitse de Molly'nin monoloğunda erkeksi zamirleri görüyoruz. Yani Bayan Dalloway'deki gibi Molly'nin duyarlı kadın sesini duyamıyoruz çünkü bu kadın karakter bir erkek bakış açısıyla yaratılmış ve evlilik teklifine bir kadının nasıl tepki verebileceğini hayal eden bir erkek yazar tarafindan kaleme alınmıştır. Dolayısıyla, Molly kadın bakış açısıyla gerçek bir kadının sesini ve hislerini veremez.

Diğer bir fark ise kullanılan noktalama işaretleridir. Dorrit Cohn'un dediği gibi "karakterleri hiper-aktif hale geldiğinde, dünyası fazla karmaşık, yönelimi fazla gerçekçi olduğunda, türün kendi iç matrisine döngüsel (veya spiral) dönüşü teorisi muhtemelen tartışlabilir" (1978, s. 9). Modernist romancıların iç dünyayı "döngüsel (veya sarmal)" olarak yakalama tekniğini Woolf bilinç akışı tekniğiyle noktalama işaretlerini kullanarak uygular. Woolf bilinç akışını anlatmak için özellikle noktalı virgül ve virgül kullanır ve bu noktalama işaretleri arasında bir karakterin bilinç akışından diğerine atlar. Bu sarmal hareket önemlidir çünkü "zamanın içinde yazı ritminde zihnin -yukarı, aşağı / iç, dışsal- bir 'hareketini' yakalar" (15). Woolfun anlatımı noktalama işaretleri yardımıyla bilinç akışı yüzeyden karakterlerinin derinliklerine doğru hareket eder; örneğin, Bayan Dalloway'de Woolf, arkadaşı Peter Walsh onu ziyaret ettiğginde sinirlendiği için Dalloway'in bilinç akışını parantez içinde verir:

\section{Clarissa, bunun ne kadar olağanüstü bir alı̧keanllk olduğunu düsündü; her zaman çak.zyla oynamasmm. Daima insan da aşır, havai hissettirir; boș fikirli, sadece aptalca bir sobbet kutusu, onun yaptiğg gibi. Ama ben de diye düssündü ve iğnesini eline alarak, gardiyanlar uyuy a kalmıs ve korumasız burakılmuş bir Kralice gibi emretti bu

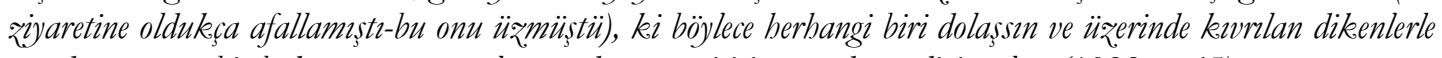 nerede yatthğna bir baksin, yaptı̆g seylere yardim etmesi için çă̆grdl; sevdiği seylere (1922, s. 65).}

Woolf un Mrs Dalloway romanı Humphrey'in dolaylı iç monolog tanımı için de iyi bir örnektir. Romanın ana karakteri Bayan Dalloway'in düşünceleri serbest çağrışım yoluyla birbiri ardına takip eder. Büyük bir parti hazırlı̆̆1 içinde olan Bayan Dalloway, hizmetkarı Lucy'in yoğun olması sebebiyle, çiçekleri kendisi almaya gittiğinde kapıdaki menteşenin gıcırtısı onu Peter'ın sinirli bir şekilde çakısı ile oynadığı ana götürür. Anlatım, dışarıdan bir nesne olan Peter'n çakısıyla başlar ve Clarissa'yı daha derin iç dünyasına götürür. 
Peter'ın fiziksel alışkanlığına ayrıntılı bir gönderme yaparken Clarissa’nın içsel düşüncelerini anlatır. Bir hikâyeden diğerine akan bilinç akışı kadınların düşüncelerindeki ani değişen akışları ve ayrıca kadınların ayrıntılı tanımlarını gösterir. Michael H. Whitworth, "Woolf un bu diyalog tesiri ile modernist çağdaşlarıyla karşılaştırılabileceğini, ancak ayrıntıları ve üslubu bakımından onlardan ayrılabileceğini” iddia eder (2010, s. 107). Woolf düşünce ve bilinç akışının, spiral bir yolla her seferinde nasıl daha derinlere daldıklarını ve aynı zamanda dış dünyaya nasıl kolaylıkla çıkabildiklerini anlatır. Yani, Woolf un noktalama işaretleriyle bilinç akışını kullanma biçimi, Joyce’unki gibi doğrusal olmaktan çok spiraldir.

Woolfun aksine Joyce, bilinç akışı yöntemini düşüncelerin doğrusal bir yönde aktığı doğrusal bir yolla anlatır. Bu da bize kadın anlatımının duyarlı, döngüsel ve sarmal, erkek anlatımının rasyonel, doğrusal ve düz-hat sürekliliği içinde olduğunu gösterir. Örneğin, “The Dead” (“Ölüler”, 1914)5 adlı kısa öyküsünde, Gabriel arkadaşı Miss Ivory'nin övgüsüne kızar, ancak tepkisi duygusal olmaktan ziyade çok rasyoneldir; "onun suçlamasını nasıl karşılayacağını bilmiyordu. Edebiyatın siyasetin üstünde olduğunu söylemek istedi. Ama onlar yıllarca ayakta duran arkadaşlardı ve kariyerleri paralel ilerledi, önce üniversitede, sonra öğretmen olarak" sonra mantıklı bir şekilde "onunla görkemli bir ifadeyi riske atamayacağına karar verdi. Gözlerini kırpmaya ve gülümsemeye çalışmaya devam etti ve kitap eleştirilerini yazarken politik hiçbir şey görmediğini mırıldandı" (Joyce, 2011, ss. 19-20). Böylece okuyucu olarak Gabriel'in daha derin duygularına değil, entelektüel zihnine dalarız.

Joyce, karakterlerinin bilincini tanımlarken serbest dolaylı konuşma, dolaylı aktarım veya deneyimli konuşma yöntemlerini kullanır. Örneğin yine "The Dead"'de anlatıc1 Gabriel karakterinin ne düşündüğunnü şöyle anlatır; "Bir saat önce duygularının kökenini merak etti" ama ardından anlatıcı Gabrail'in kendi düşüncelerine atlar; "Nereden başlamıştı? Teyzesinin akşam yemeğinden, kendi aptalca konuşmasından, şarap ve danstan, salonda iyi geceler derken neşe uyandırmasından, karda nehir boyunca yürüyüşün zevkinden. Zavallı Julia Teyze! O da yakında Patrick Morkan ve atının gölgesi olacaktı" (2011, s. 62). Zavallı teyze diye düşünenin anlatıcı değil Gabriel olduğunu anlaşılır. Joyce’un eserlerinde anlatıcının sesi ile karakterin sesi arasındaki örtüşmeyi sınırlı noktalama işaretleriyle görürüz, bu nedenle "anlatının parçalanması genellikle olağandışı bağıntı ile veya normal şekildeki bağlayıcı cümleler, paragraflar ve anlatımdaki değişikliklerle sunulur;" ve dolayısıyla bu tarz "alıșllmadık sıçramalara, yan yana birleştirmelere ve bağlantılara yol açar ve bu da genellikle beklenmedik görsel veya grafolojik etkiler yaratabilen olağandış1 veya eksik noktalama işaretleriyle belirtilir" (Carter ve McRae, 2001, s. 389). Kısacası, Joyce doğrudan bir geçişle Gabriel'in düşüncelerine girer ama Woolf un yaptığı gibi noktalama işaretleri arasında karakterin duygularına ve derin hislerine girmez.

\section{Joyce'un Epifanı ile Woolfun Varolma Anları}

Frederick R. Karl'a göre, bilinç akış “modernizmin ta kendisidir” (1998, s. 239). Hem Virginia Woolf hem de James Joyce eserlerinde bu yeni biçemsel yöntemi kullanmışlardır. İkisi de öznel, gizli fikirleri, söylenmemiş hisleri ve karakterlerin izlenimlerini sunmak için bu biçemsel tekniğine odaklanırlar. Robert Humphrey Stream of Consciousness in the Modern Novel (Modern Romanda Bilinç Akışı, 1954) adlı çalş̧masında bu tekniği “öncelikle karakterlerin psişik varlığını açığa çıkarmak için bilincin ön konuşma seviyeleri” olarak adlandırır (1954, s. 4). Harry Dexter Kitson ise şöyle düşür: akış "bireyin içinde devam eden zihinsel süreçlerin bütünü içerir: fikirler, duygular, istemler ve eylemler” (1921, s. 4). Bu durumda, Woolf ve Joyce bilinç akışı tekniğini farklı şekillerde kullanırlar. Woolf ve Joyce bilinç akışı tekniğinin öncü yazarları olsalar da bilinç akışının ana yöntemleri olarak kabul edilen Joyce'un epifanı ve Woolf un varolma anları farklı anlatım tarzları açısından ayrışırlar.

Woolfun önem anı (moments of importance) ve Joyce'un epifanı İngiliz modern kurgusunda bilinç akışı yönteminin karakteristik anlatım tekniğidir. Her iki yazarın zihinsel deneyim anını yansıtma çabaları bu iki farklı tekniğin ortak özellikleridir. Joyce'un on beş kısa hikaâyesinden oluşan Dublinhlier (Dubliners, 1914) eserindeki "Bir Küçük Bulut" ("A Little Cloud," 1914) kısa hikayesinde Küçük Chandler'in epifanı ve Woolfun "Duvardaki İz" ("The Mark on the Wall," 1917) adlı k1sa hikayesindeki duvardaki iz anı karakterlerin iç düşüncelerini ortaya çıarmalarına sebep olur. Her ikisi de dış dünyadaki bir uyaranın, nesnenin insan zihni üzerindeki etkisine ihtiyaç duyarlar. Chandler arkadaşı Gallaher'in aşağılayıcı ve karısının alaycı konuşması ile ani bir epifan anı yaşar ve bu da karakterin iç düşüncelerini ortaya çıararak karakterin Dublin'deki umutsuz yaşamını fark etmesine sebep olur. Aynı şekilde duvardaki iz, Woolf un karakterinde bilinçaltındaki karmaşık duygu ve düşünce akışına sebep olur. Her iki anlatım tekniği de

\footnotetext{
${ }^{5}$ Bu hikâye, Dublinliler romanın son ve en uzun öyküsüdür.
} 
yorumsal analizden öte bilinç akışı anlarını göstermeyi hedefler çünkü her iki yazar da geleneksel romanda olduğu gibi üzerine yorum yapmazlar sadece karakterlerin duygusal tepkilerini ve düşünce akışlarını yansıtırlar. Diğer bir deyişle, yazar karakterleri tanıtmaz ancak karakterler kendi düşünce ve duygu akışları ile kendilerini tanıtırlar ve bu da okuyucuların hayal güçlerini geliştirmelerine olanak sağlar. Hem Joyce hem de Woolfun bilinç akışı tekniği karakterlerin psikolojik deneyimini sunar. Tüm öykünün dışsal gelişimi, Joyce'un ve Woolf un çalışmalarındaki karakterlerin iç deneyimleriyle anlatılır. Bilinç akışı, karakteri kendi iç dünyasına götüren dış dünyanın etkisinden kaynaklanır. Bu modern teknik, anlatmaktan ziyade karakterlerin bilinç akışını göstermeyi amaçlamaktadır, bu nedenle metinlerin sonunda doğrudan bir mesaj olmadığı için okuyuculardan kendi hayal güçleri ve yorumlarıla anlamaları beklenir.

Joyce, Dublinliler, Uysses, Sanatçnn Bir Genc Adam Olarak Portresi ve Finnegan'in Vahı (Finnegan's Wake, 1939) gibi eserlerinde çeşitli epifan biçimleri kullanır (Cuddon, 2013, s. 244). Örneğin, Kabraman Stephen (Stephen Hero, 1944) eserinde "epifan ile ani bir manevi epifanı" kasteder ve iki tür epifan biçiminden; "ister konuşmanın veya hareketin bayağllğında ister zihnin unutulmaz bir evresinde olsun, ani bir tinsel belirişinden" bahseder (Joyce, 1955, s. 216). Stephen, Cranly'ye "Ballast Ofisinin saatinin epifan kabiliyetine sahip olduğunu" söylediğinde epifana nasıl ulaştığını açıklar: "Gözümün o saate ilişmelerini, bakışını gerçek bir odak noktasına ayarlamaya çalışan bir ruh gözünün uğraşları gibi düşün. Odağa ulaşttğı anda epifan olayı gerçekleşmiş demektir. Güzelliğin yüce niteliğini, üçüncü olanı tam da bu epifanda buluyorum” (Joyce, 1955, s. 211). Woolf un "Duvardaki İz" anlatısı ise bilinç akışı tekniğini bir önem anı olarak kullanmasının güzel bir örneğidir çünkü duvardaki iz birbiri ardına gelen bilinç akışına neden olur. Yani, "özel iç görü anları Joyce tarafindan epifanlar ve Virginia Woolf tarafindan da varolma anları olarak adlandırilır” (Booker, 1995, s. 10). Woolf, "Duvardaki İz" de bir ana odaklanarak bir tür içsel zihinsel etkinliği ve psikolojik deneyimi yansıtır.

Öte yandan, Woolf ve Joyce'un bu iki benzer tekniği kullanmaları anlatım teknikleri açısından bazı ayrışan farklılıklar barındırdığını gösterir. Joyce'un epifan tekniği hikâyenin olay örgüsü ile oldukça yakından ilintilidir; örneğin, "Bir Küçük Bulut" hikayesinde olay örgüsü ilerledikçe Küçük Chandler kaçınılmaz gerçekliği epifan olarak deneyimler, yani olay ile epifan doğru orantılıdır. Ancak Woolf un önem anı tekniği "hızlı, rastlantısal ve parçalanmış" anları bünyesinde barındırır; örneğin, "Duvardaki İz" hikâyesinde duvardaki iz karakter tarafından sürekli farklı görüntülerle tekrar edilir ve bu da "ani, rasgele ve parçalı" bir görüntü sunar (Jin, 2011, s. 117). Dahas1, Joyce'un epifan tekniğinde, bazı ahlaki veya sosyal önemi olan zihinsel ikilemden kaçmak isteyen karakterin son epifanında bir çözünme görürüz, ancak Woolf un önem anı, herhangi bir çözünme olmaksızın sürekli bir zihinsel eylem sürecidir. Mahaffey'in "dramatik epifan" (2004, s. 187) olarak adlandırdığı öykünün sonunda Joyce’un epifanı olay örgüsünün gelişiminin doğal bir sonucu olarak hizmet ederken, Woolf un önem an1, herhangi bir olay örgüsü veya mantıksal sıra olmaksızın bilincin serbestçe genişlemesine hizmet eder. Belli zaman ve yerde oluşan hikâyenin ani doruk noktasında epifan oluşur ve hikâye aniden sonlanır; örneğin, "Bir Küçük Bulut" da hikâye küçük Chandler'ın hayatın anlamını bulduğu anda biter. Ancak önem anı karakterin iç dünyasının sürekli akışını yansıtır; örneğin, karakterin iç dünyasına dalış tetikleyen duvardaki izin anlatıcı tarafından sonunda salyangoz olarak fark edilmesi ile hikâye kesintiye uğrar. Yani, Joyce’un epifanı olay örgüsünde doruk noktası rolünü oynarken, Woolf un önem anları, doruk noktası olmayan sürekli bir düşünme sürecidir. Sonuç olarak hem Joyce hem de Woolf için bazı farklılıklar olsa da "önemsiz bir an ve sıradan bir nesne ani bir epifan olarak 1ş1k parlamasını ortaya çıkarabilir” (Concilio, 1999, s. 281).

Modernist roman geleneksel romanın zaman, mekân ve mantık birliği kuralını yıkar ve hikâyeler ya açı uçlu veya sonu olmayacak şekilde biter, hatta hikâye daha başlamadan biter veya başladığı noktada biter. "Duvardaki Iz" hikayesi örneğin duvardaki iz ile başlar ve yine duvardaki izin salyangoz olduğunun fark edilmesi ile biter, yani bir saatten kısa bir süre içerisinde karakterin iç dünyasına dalıp çıkarak yine başladığ1 zamanda biter. Woolfun "Duvardaki İz" eserinde modernist zaman ve bilinç muğlaklaşır. Örneğin geleneksel romanın aksine bu modernist hikâyenin ne zaman ve nerede başladığı net değildir. Karakterin bilinç akışı nereye akıyorsa orada başlar ve bu da kullanılan zaman eklerinden de anlaşılacağı gibi zamanı bulanıklaştırır:

Belki de içinde bulunduğum ynlin Ocak ayımn ortalarnda ben ilk kez yukarı bak tım ve duvardaki işareti gördüm. Bir taribi düzeltmek için birinin ne gördü̈ü̈nü hatorlaması gerekir. O yü̈den şimdi ateşi düsünüyorum; kitabımın sayfasmdaki sabit sar ışık filmi; şöminenin üzerindeki yuvarlak cam kâsede ǚ krizantemi" (Woolf, 1919, s. 1).

Bu hikâye cümleye geçmiş zamanla başlar, geniş zamana geçer ve şimdiki zaman ile bitirir. Karmaşık zaman sürelerini kullanması bize karakterin zihin akışının karmaşıklığını göstererek iç dünya akışını ve 
deneyimlerini yansıtır ve bu da modernist zamanın bilinç akışı ile doğru orantılı bir şekilde nasıl muğlak ve kırılgan olduğunu yansıtır. Tüm hikâye işte bu duvardaki iz ile karakterin düşünce akışında ilerler. Bu örnekte olduğu gibi Woolf bir anı sabitler ve duvardaki iz anı karakterin bilinçaltındaki akışlara can veren diğer önemli düşünce ve duygu akışlarına yol açar. Karakter duvardaki ize çeşitli tanımlar yaparak bilinç akışını bizlere gösterir ta ki bu izin bir salyangoz olduğunu anlayana dek. Woolf yaklaşı yarım saat bile sürmeyen bu önem anı anlatısında karakterin iç dünyasına inerek düşüncelerini, duygularını, hayallerini, hatıralarını ve umutlarını yansıtan karmaşık zaman ve bilinç akışlarını gösterir.

Joyce'un romanları gibi, Woolfun romanları da okuyucudan farklı bilinç akışının sunulduğu özne konumuyla kendilerini özdeşleştirmesini ister, böylece okuyucu modernizmin özelliklerinden biri olan bölünmüş şahısları görür. Ayrıca okuyuculardan sıradan bir konuyu sıradan bir günde sadece bir anlığına incelemelerini ister. Her iki yazarın da zamanın gücünü kullanması sadece bir gün içinde gerçekleşir; örneğin hem Bayan Dalloway hem de Ulysses tek bir günü anlatır ama karakterlerin bilinç akışları yardımıyla geçmişleri hakkında daha çok şey öğreniriz. Herhangi bir diş nesne, karakterlerin kendi iç deneyimlerine, zihinlerine ve duygularına dalmalarına yardımcı olur, bu nedenle her bir bilinç akışına geçiş esnasında dışarıdaki tek bir günden sonsuz zaman dilimine geçiş yaparız; örneğin, Woolf Clarissa'nın sadece bir gününü anlatan Bayan Dalloway'de Clarissa Bond Caddesi'nde yürürken vitrinlere bakar ve aniden düşünceleri dış nesneden uzaklaşıp kendi iç geçmiş deneyimlerine ve kendi duygularına geçiş yapar:

Savaştan önce neredeyse mükemmel eldivenler alabileceğiniz bir eldiven dükkânmm cammmn karşssmnda durdu. Ve yassh amcası William, bir bayan ayakkabularn ve eldivenleriyle tanmir derdi. Savassin ortasinda bir sabah yatağnna dönmïstï. Demisti ki, "Yeterince sabiptim." Eldivenler ve ayak.kabular; eldivenlere tutkusu vardı [Clarrisa]; ama tek kin, Elizabeth', her ikisi de zerre kadar aldirmiyordu (1922, s. 15).

Bu eldivenler Clarissa'ya William Amca'yı, savaşı, ölümü ve kızından yabancılaşmasının yarattı̆̆ acıları hatırlatır. Woolf romanı boyunca, karakterlerin iç gözlemleri ve anımsamaları yoluyla bize bilinç akışı yöntemini gösterir. Humphrey'e göre "bilinç-akışı yazarı iki şey yapması gerekir: (1) bilincin gerçek dokusunu temsil etmesi gerekir ve (2) okuyucu için ondan bir anlam damitması gerekir" (1954, s. 63). Hem Joyce hem de Woolf bu iki kurala uymuştur ve Humphrey'in de kabul ettiği gibi, bu teknik Woolf ve Joyce ile birlikte yükselmiştir.

Patricia Ondek Laurence, Woolf un "Modern Fiction" (Modern Kurgu) adlı denemesinde Woolf un “"derinliklerdeki' düşünce, duygu ve bedensel hislerin hareketini ve yaşamın 'yüzeyindeki' gerçekleri, olayları ve eylemleri yakalamak istediğini” iddia eder (1991, s. 13), çünkü Woolf, “Atomları zihne düştükleri sırayla kaydedelim, her bir görüntü veya olayın bilinç üzerinde attığı çentiğin dış yüzeye bağlantısız ve tutarsız olan çizdiği desenini izleyelim. Genelde küçük olduğu düşünülen şeyde hayatın tam olarak daha fazla var olduğunu hiçe saymayalım" diye salık vermiştir (Woolf, 1953, s. 246). Woolf, karakterlerinin bilinç akışını hayatın yüzeysel olaylarından zihnin iç düşüncelerine yani zihnin ta derinliklerine kadar anlatır.

Dahası, Woolf birden fazla zihni anlatır, karakterlerinin bilinç akışını birden çok perspektiften yansııı ve en önemlisi de "Joyce gibi diğer modernistlerden ayrılan bir yolla okuyucu romana davet edilsin diye dili açık uçlu" bırakır (Laurence, 1991, s. 25). Dolayısıyla, okuyucular olarak kimin konuştuğu konusunda kafamız karışır, bu yüzden "Joyce’un aksine, Woolf Joyce'un yapmadığı bir şekilde dile güvenmeyerek anlatı ve tematik sessizlik konularına çekilmiştir" (Laurence, 1991, s. 182). Joyce'un anlatımı görsel olup göze hitap ederken, Woolf "söylenen kelimeyi değil şiirselliği en üst düzeye çıkarır ve yazısındaki sessizlik 'gözlerin arkasında' [...] ve kulakların arkasında hissedilen şeydir" (Laurence, 1991, s. 183). Yani Woolf un romanları, Joyce'un romanlarına göre daha çok sessizlik ve şiirsel üslupla ilgilenir.

Ayrıca Woolf, Joyce’un tarzı için “muhtemelen size çok yavaş, bir tavşanın nasıl zıpladığını çok yavaş gösteren bir sinema gibi; tüm resimler biraz önce yapılmışı”" (Henke, 1986, s. 40) ${ }^{6}$ diyerek kendi yazdıklarını resimsel değil dilbilimsel olarak gördüğü için hiçbir zaman sinematik olarak değerlendirmemiştir. Humphrey sinematik cihazları “'montaj,' 'çoklu-görünüm,' 'yavaşlatmalar,' 'karartma,' 'kesik,' 'yakın-çekimler,' 'panorama' ve 'geriye-dönüşler' olarak tanımlar (1954, s. 49). Joseph Collins'e göre 'kısa bir süre için, Bay Joyce, 'filmler' ile ilişkilendirildi ve Uyysses'in rol aldığı form, sinematograf girişiminin adı verildiği gibi Volta Tiyatrosu'ndaki deneyimler tarafindan önerilmiş olabilir"' (1923, s. 50). John Middleton Murry ise Joyce tarafından kullanılan bilinç akışının "arasız ve olay örgüsüz yirmi-dört-saatlik bir sinematograf kadar yorucu olabileceğini”" ve "aklın süreçlerini kaydetmeyi” durduramayacağını savunur (1923, ss. 298-99). Yazar aslında

\footnotetext{
${ }^{6}$ Ayrica bkz. The Philosopby of Advertising in Theory and Practice: A Simple Exposition of the Principles of Psychology in their Relation to Successful Advertising, ed. Walter Dill Scott, Boston: Small, Maynard and Company, 1921, p. 643.
} 
iç monolog ile "aktarma görevini bırakır; okura roman kişisinin zihnini bir sinema gibi seyrettirir" (Moran, 2003, s. 77).

Joyce, kendi bilinç akışı tekniğiyle, sahneyi bir tür sinematik efekt olarak çoklu görünümlerde göstermek için zamirlerle oynar. Örneğin, Joyce Ulysses'de zamirleri sürekli değiştirir: "Stephen çizmelerinin çatırdayan kırıntıları ve mermileri ezdiğini duymak için gözlerini kapattı. Her nasılsa içinden yürüyorsunuz. Ben her seferinde bir adım atıyorum" (1922, s. 37). Joyce burada pasajdaki anlatıya üçüncü şahıs kişiyle başlarken, ikinci şahıs kişiye sonra da birinci şahıs kişiye geçer. Sadece sinematik anlatı yöntemi ile değil aynı zamanda bilinç akışını en iyi ifade eden tekniklerden biri olan epifan tekniği ile karakterlerin iç dünyalarına bir akış gerçekleştirir.

\section{Epifan}

Epifan genel olarak dini bir terim olarak kullanılmıştır. Aslında “Tanrı'nın yeryüzünde tezahürü demek olan epifan, sanatçılar tarafindan bu bağlamda kullanılmıştır. Özellikle mistik ve dindar şairler 'epifan' yaşadıklarını, 'ilahi’ olan ile temasa geçtiklerini”' ileri sürmüşlerdir (Öğretir, 2005, 6). Bu dini ve mistik misyonun dışında, "[k] üçük, sıradan ve bilindik görünen olguların insan yaşamında aslında önemli olduğu veya olabileceği gerçeğine dikkat çekme arac1/tekniği de olan epifan, metinlerde bireysel sinırları aşıp, toplumsal ve evrensel boyutta başka bireylerle ortak paydalar kurulmasına zemin hazırlar" (Koçsoy, 2018, 116). Böylece anlık tinsel tezahür olarak epifan sezişler, duygular ve düşünceler eşliğinde öznel içsel deneyimleri aşarak evrensel boyuta ulaşabilir.

Realist karakterler, önemli bir şey üzerinde ve açı nedenlerle epifan deneyimleri yaşarlar. Örneğin Charlotte Brontë'nin Jane Eyre (1847) romanında tıpk1 kör olan Rochester'ın yanındaki kadının Jane olduğunu epifan deneyimlediği andır. Olay anlatıcı Jane tarafından sadece bir kez anlatılır ve kronolojik anlatı yapısı bozulmaz. Ancak Modernist epifanlar farklı anlatım teknikleri ile yansitilır ve zaman ve kronolojik yapı bozulur İlk başta zar zor fark edilen ve onu deneyimleyen kişi dışındaki herkes için önemsiz görünen bir aydınlanma anı anlatılarıdır. Bu yüzden bu tarz epifan anları karakterler için zaman duygusunu yeniden şekillendirilir ve "hikâyeyi anlatırken anlatıcılar için akronolojiyi gerekli kılarlar" (Kern, 2011, s. 122).

Morris Beja epifanı "onu üreten her şeyin önemi veya kesinlikle mantıksal ilgi düzeyiyle orantısız olarak" tanımlar (1971, s. 18). Woolf un Deniæ Fenerìindeki Lily Briscoe önemli modernist epifanları yavaş yavaş yaşar. Lily nihai görüş anını, resmini tamamlayabilmek için önemli olan bir ağacı başka yere hareket ettirmeyi düşünürken yaşar, bu ağaç anı bir başkası için önemsiz bir şeye dönüşürken epifan deneyimi yaşadığı nokta karakter için zamanla çok daha önemli konuları kapsayacak şekilde ortaya çıkar. Roman başladığı gün, "bir zamanlar açıkça gördüğü ve şimdi çitlerin, evlerin, annelerin ve çocukların arasına el atması gereken bir vizyon" (Woolf, 1937, s. 82) çizmeye başlar. Lily'nin ikinci görüş anı, o gün sanatından aldığı hazzı düşünürken ortaya çıkar: "Bir anda resmini gördü ve şöyle düşündü, Evet, ağacı daha da ortaya koyacağım; o zaman bu garip alandan kaçınabilirim" (Woolf, 1937, s. 128). Ağacı hareket ettirmesini hatırlatmak için masa örtüsünün üzerindeki çiçek desene bir tuzluk koyar. O günün ilerleyen saatlerinde, aşkın acımasızlığını düşünürken, epifanlar ortaya çıkmaya devam eder: "Zaten, desenin üstündeki tuzluğu görünce kendi kendine şükürler olsun ki evlenmek zorunda olmadığını böyle bir tezellüle gerek kalmadığını söyler. Bu hezeyandan kurtulmuştu. A ̆̆acı daha çok ortaya doğru hareket ettirmeliydi” (Woolf, 1937, s. 154).

Bu iç görü on yll sonra Bayan Ramsay öldükten sonra eve döndüğünde ortaya çıkar ve epifan deneyimi kendi üretken seyrine devam eder: "Aniden hatırladı. Geçen on yll önce orada oturduğunda, masa örtüsünün üzerinde, bir aydınlanma anında baktığ 1 küçük bir dal ya da yaprak deseni vardı. Resmin ön planıyla ilgili bir sorun olmuştu. Ağacı ortaya çek, demişti kendi. O resmi hiç bitirmemişti. Şimdiye o resmi boyamış olacaktı" (Woolf, 1937, s. 220). Yaratıcı içgüdüler onu dürttükçe eylem şiddetle artar. Kompozisyonda Bayan Ramsay ve oğlunu hayal ederek on yll önce olduğu yerde oturur. Bütün bu yıllar boyu eksik resim zihnine takılmıştı. Epifanın doruk noktası ile resmi ve romanı tamamlar: "Sanki bir an için net görmüş gibi ani bir yoğunlukla, oraya, ortaya bir çizgi çekti. Yaptı; bitti. Aşırı yorgunlukla firçasını bırakarak evet diye düşündü. Vizyonum vardı" (Woolf, 1937, s. 310). Romanın bu satırları bize modernist epifanın bazı özelliklerini gösterir. İlk ve son olaylar önemsizdir: ağacı ortaya taşıma olayı ve resmin ortasına bir çizgi çekme olayı.10 yll içinde olay güç kazanır ve aşk, evlilik, sanat gibi diğer oldukça önemli olaylara değinir. Bu önemli olaylara etkisinin ortaya çıkmasının hayli vakit alması ve etkisinin oldukça geniş olması metin içinde sürekli geri dönüşleri gerekli kılmıştır. Bu tarz yeniden anlatımlar ana anlatıyı etkilese de Lily'nin örneğinde olduğu gibi kişisel ve sanatsal anlatımlar epifanın en sık kullanılan şeklidir (Kern, 2011, ss. 123-4). 
Joyce ise sanatçı olmak için genç bir adamın oluşum serüveninde estetik ve psikolojik bir etki yaratmak için Sanaţ̧ını Bir Genc Adam Olarak Portresi romanında hem bilinç akışını hem de epifanı birleştirmiştir. Joyce'un iç monolog tekniğinin benzersiz özellikleri ve bu romandaki epifanların sanatsal etkisi oldukça etkileyicidir. Ana karakterin "önemli bir dönüşüm veya değişim geçirmesi beklenmekte” (Kümbet 84) olan bu oluşum (Bildungsroman) romanında genç bir adamın sanatçı olabilme yolundaki olgunlaşma sürecini ve sanatçı (Küntslerroman) romanı olarak da bu genç sanatçının geçirdiği değişimleri anlatır. Romanın başındaki ve en sonundaki epifan anı en önemli örnekler arasında sayılabilir. Romanın ilk başındaki küçük epifanlar Stephen'ı romanın sonundaki olgunlaşma ruhaniyetine götüren onu hayata, topluma, dinine ve sanata bakışını değiştiren büyük epifanlara hazırlar. Dördüncü bölümün sonunda, Stephen rahipliği düşünerek eve dönerken bir Meryem Ana mabedinin önünden geçer ancak büyük bir manevi soğukluk hisseder. Sanki yakında kendisine ait olan ve başkaları tarafindan kontrol edilmeyen yeni bir ruh yaratmaya başlayacakmış gibi hisseder ve tam bu ruhsal aydınlanma anında denizden geçen güzel bir kız görür ve bir manevi berraklık ve sanatsal bir kabiliyet duygusunu fark eder. Meryem Ana ve bu gördüğ̈̈ kız ile ruhsal ilhamını pekiştirir. Bu epifan anı ile ruhundaki ani bir değişime tanık olur. Rahip olmanın eşiğine geldikten sonra iç benliğindeki bu ani ruhsal değişim ile rahiplik kararından vazgeçer ve sevinç çı̆̆lıkları ile güzelliğin felsefi ve estetik yönünü takip etmek için sanatçı olmaya karar verir: "Kutsal Tanrı! Dünyevi [Profan] bir sevinç patlamasıyla Stephen'ın ruhu ağladı" (Joyce, 1964, s. 186). Epifan tekniği ile karakterin ruhsal aydınlanma anlarını, genç bir adam olarak çocukluktan yetişkinliğe doğru bilinç akışını ve sanatçı olma yolundaki gelişimsel portresini çizer. Joyce'un bu iki bilinç akışı ve epifan tekniği, genç sanatçının psikolojik, ruhsal ve zihinsel gelişimini yansıtır.

Harry Levin, Joyce’un Dublinliler'inin tamamen epifanlar koleksiyonu olduğunu söyler (1960, s. 28-31) ve aynı şekilde William Tindall'da her bir hikâyenin "küçük epifanların kapsayıcısı ve epifanların epifanı yani büyük bir epifan olarak düşünülebileceğini” söyler (1951, s. 11). Ancak Joyce’un kendisinin basılmamış eseri Stephen Hero (daha sonra Sanaţ̧mm Bir Genç Adam Olarak Portresi’e dönüşmüştür) eserinde asıl epifanı tanımladığı ve artık epifanın semboli haline gelmiş olan Stephen'ın genç hanımı gördüğündeki epifan deneyimi hali epifanın en önemli örneklerinden birisidir. Kabraman Stephen'da Joyce, okuyucuyu Stephen'nn teorisi hakkında bilgilendirmek için iki anlatım tekniği kullanır. İlk olarak anlatıcı olan Stephen epifan anlatım tekniğini nasıl tasarladığını dile getirir:

\begin{abstract}
Bir aksam Eccles [Bloom'larm sokağg] caddesinden gecigordu, sisli bir aksam, ... Genc bir hanmm İrlanda Felcinin [Dublinliler'in ana temasi] bizzat vücut bulmus hali gibi görünen kahverengi tuğlal evlerden birinin basamaklarnnda duruyordu. Genc bir bey bölgenin pash parmakliklarna yaslanmıstı. Stephen kendi bedefinin

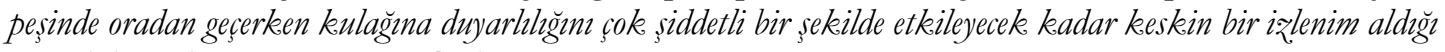
aşağrdaki şu konusma parçasi çalındr:
\end{abstract}

Genç Hanım — (ihtiyaten ağır ağır konuşarak) ... O, evet . . Ben . . şa . . pel . . deydim ...

Genç Bey — (duyulamaz bir şekilde) . . Ben . . . (yine duyulamaz şekilde) . . Ben . . .

Genç Hanım — (alçak sesle) ... O . . ama sen ... de . . çok . . yara . . maz . . sin. . .

$\mathrm{Bu}$ önemsiz olay ona bu türden pek çok anı bir epifanlar kitabında bir araya getirmeyi düşündürdü. Epifan ile, ister konuşmanın ya da jestlerin bayağılığı, isterse zihnin kendisinin unutulmaz bir aşamasında olsun, ani bir manevi epifanı kastetti. Epifanların en hassas ve uçucu anlar olduğunu görerek, bu epifanları son derece dikkatli bir şekilde kaydetmenin edebiyatçıya düştüğüne inanıyordu (Joyce, 1955, ss. 210-211). İsmail Öğretir'e göre:

\begin{abstract}
Modernist bir yazar olarak Joyce'un da, epifan üzerinde önemli ölç̈de kafa yorduğunu ve bu konuda kuramsal çalıs̆malar yaptrğgn görmekteyiz: Genel sanat anlayıšs çerçevesinde geleneksel olana karşı ģı.ma eğgiliminde olan yazar, epifan kavramm öncelikele dinsel bağlamindan koparp tümüyle dünyevileștirmiștir. Ona göre, yaz̧arn görevi, "profan rabiplik" tir. Bu yüzden kendisi, epifan, yazarn siradan bir olay ya da dïsïnceyi sanatı arachliğzyla zaman dışı bir güzęlliğe dönüsțtürme işleminde kullanmıştrr. Joyce'un ikinci kişiliğ̈ne bürünen Stephen Dedalus'un belirttiği gibi, bu öyle bir andır ki en siradan nesnenin rubu bile ışık saçarak. biže ulaşır $(2005,13) .7$
\end{abstract}

Bunu takiben Stephen Cranly'ye epifan tekniğini Aquinas'tan türettiği estetik anlayıştaki üç aşamayla ilişkilendirdiğini ve estetik kaygının üçüncü ve son aşamasıyla birebir ilişkili olduğunu anlatır. Nesnenin bütünlügü ve simetrisi anlaşıldıktan sonra parlaklığı anlaşılır. Yani aklın analiz aşamasından sonra en son aşamada sentez yaptığını ve üçüncü niteliği yani epifanı keşfettiğini anlatır. İlk aşamada nesneyi bir bütün

\footnotetext{
${ }^{7}$ Öğretir son cümlesinde David Lodge’un Kurgu Sanatı (Art of Fiction, 1992) eserine referans verir (s. 146).
} 
olarak gördüğümüzden, ikinci aşamada bu nesnesin bileşik bir yapısını fark ettiğimizden ve son olarak da parçaların muazzam ilişkisinden ve bir noktaya odaklanmasından nesnenin ruhunun bize 1şıltıll göründüğü epifan deneyimimizin gerçekleştiği andan bahseder. Dolayısıyla, Stephen nesnenin epifan deneyimine dönüştügünü anlatır (Joyce, 1955, s. 213). Bakışlarımız tam nesneye odaklandığında o nesne epifanize olur. Bu nesne duvardaki bir iz, asılı duran bir saat, taksi, çiçek veya bir kişi olabilir. "Böyle anlarda kaba dış gerçeklik, algıllayan için bir tür aşkın anlam taşır" (Öğretir, 2005, 81) Kısacası, epifan dışsal veya içsel bir uyaranın sebep olduğu ani bir aydınlanma ve ruhsal evrim anıdır.

\section{Önem An1-Varolma Anı}

İşte Woolf da Bayan Dalloway'de karakterlerin farkındalı̆̆ını belirli bir andaki durumlarına yansıtmak için "Varolma Anları" adını verdiği teknik ile karakterlerin iç dünyalarına bir gezinti sunar. İlk kez bu teknikten "Geçmişin Eskizleri" ("A Sketch of the Past," 1939) adlı otobiyografik makalesinde bahseder. Hayatında diğer hatıralardan daha çok yoğun hatırladığı önem anlarından bahseder. Dış veya iç faktörlerle uyarılabilen derin iç görü ve bilinçlilik hali oluşturan bu yoğun anlara "Varolma Anları" adını verir. Ancak, varolma anının tersini temsil eden bazı anların da olduğundan bahseder: "var-olmama anları" (Woolf, 1985, s. 70). Yani Woolf gerçekte varolma anı olmayan her şeyi var-olmama anı olarak görür. Mary Ann Gillies'in de dediği gibi "Woolfun asıl kaygısı, bir yaşamı oluşturan anlar dizisinin dışsal niteliklerini yakalamak değil, yaşamın en önemli anlarını oluşturan görünmez içsel anları yakalamaktır. Bunu yapmak için de "varolma anları" ve "var-olmama anları" olarak adlandırdığı anlar arasında bir karşıtlık geliştirdi (1996, s. 109). Yani, var-olmama anları hepimizin her gün sürekli deneyimlediği ancak farkına varmadığımız anlardır. Alışveriş veya yürüyüşe çıkmak gibi gündelik rutin yaptığımız ve kısa süreli hatırladığımız her sıradan ânımız gibi. Woolf bu bilinçlilik hali içermeyen otomatik olarak düşünmeden yaptığımız bu rutin anlara işlenmemiş ham pamuk yününe benzettiği var-olmama anları der. Ancak elbette ki bu var-olmama anları kişiden kişiye değişir, yani kişinin deneyimlediği önem anına göre değişir. Alışveriş anı nasıl ki çoğumuz için sıradan bilinçlilik haliyle anımsatmayan işlenmemiş bir ham pamuksa bir başkası için o alışveriş anı hayatındaki en önemli varolma anı olabilir. Dolayısıyla, bilinçsizce hareket ettiğimiz var-olmama anlarımızın aksine, varolma anlarımız bir dış etkenin uyarısı ile gözümüzün önünde birden canlanıveren unutulmaz farkında olduğumuz bilinçli uyanış anlarımızdır. Woolfa göre bu ilham anlarını "bir felsefe; her halükârda sabit bir fikrimdir, pamuk yününün arkasında tüm insanların buna bağlı olduğu bir örüntü gizlidir” diye tanımlar (Woolf, 1985, s. 72).

Bayan Dalloway'de Clarrisa'nın varolma anları genelde bir dış uyaran tarafindan değil kendi iç düşüncelerinin çağrışımı sonucu ortaya çıkar. Clarrisa'nın varolma anlarından birisi de çiçek almaya giderken birdenbire parkın kapısından taksileri gözlemlediği andır: "Taksileri gözlerken, hep böyle bitmek tükenmeyen bir duygu, sanki dışarıda, uzaklarda, denizin uzağında ve yapayalnız kalmış gibi bir duygu kapladı yüreğini. . . ona göre şu gördükleri müthiş çekiciydi; her şey; geçen taksiler - ve o ne Peter'1 yargilayacakt1 artık ne de kendi için ben şöyleyim, ben böyleyim diyecekti" (Woolf, 1922, s.11). Taksideki şişman kadına baktığında kendisi, çevresi ve Peter ile bağlantılı hayatı hakkında bir anlık merak duygusu kaplar içini. Dolayısıyla, Woolf varolma anları ile şimdi ve geçmişin bir arada var olduğunu gösterir, bu yüzden Clarrisa sürekli geri dönüşler ile geçmişini bugünü ile birlikte yaşar. Şu anda yaptığı sıradan bir eylem ona geçmişin kapılarını aralar ve varolma anlarına götürür. Kısacası, Joyce epifanı ve Woolf da varolma anları ile bilinç akışı tekniğini farklı anlatım teknikleri kullanarak yansıtırlar.

\section{SONUÇ}

Modernist romancilar olan Woolf ve Joyce, benzer tekniklerin yanı sıra farklı anlatım tarzlarına da sahiptir. Her ikisi de ruhsal zihin veya bilinç deneyimine daha fazla önem veren yeni psikolojik gerçekçilik kullansa da Woolf kadın yazma biçemi sebebiyle duyarlılık romancısı olarak kabul edilir. Yani Woolfun eserlerinde kadın bakış açısıyla kadınca düşünce ve duyguları görür, Joyce’a kıyasla kadınların sesini duyarız. Woolf un kadın anlatımı duyarlı, döngüsel ve sarmaldır, Joyce'un erkek anlatımı ise rasyonel, doğrusal ve düz çizgi sürekliliğindedir. Dahası, Woolf ve Joyce bilinç akışı tekniğinin öncü yazarlarıdır, ancak Joyce, sınırlı noktalama işaretiyle, zihinsel ikilemden kaçmak için bir çözüm olan epifanı kullanırken, Woolf tam noktalama işaretleri ile herhangi bir çözüme ulaştırmayan zihinsel eylemlerin sürekli bir süreci olan varolma anlarını kullanır. Öyleyse, her iki yazar tek bir günü anlatsa da Joyce'un anlatımı Woolf'ta olduğu gibi sessizlikle ilgilenmekten çok görsel ve sinematiktir. Woolf ve Joyce modern anlatım tekniklerini kullanan en önemli modernist yazarlardan ikisi olarak "savaşın muazzam şiddetinden uzaklaşarak, zaman içinde kaybedilen bir çocukluk deneyiminin istemsiz anısı, bir kızı kumsalda görmenin epifanı veya duvarda bir iz görmenin aydınlatıcı anı gibi ince ama derinlemesine açıklayıcı deneyimleri” keşfederler (Kern, 2011, s. 56). 
Sonuç olarak, anlatı tarzlarında bazı benzerlik ve farklılıklara sahip olan Woolf ve Joyce, İngiltere'deki modernist edebiyata en önemli katkı sağlayan yazarlardır.

\section{Etik Beyan}

"Virginia Woolfve James Joyce'un Modern Anlatmm Teknikleri Üzerine Karşılaştırmalı Bir Callşma” başlıklı çalışmanın yazım sürecinde bilimsel kurallara, etik ve alıntı kurallarına uyulmuş; toplanan veriler üzerinde herhangi bir tahrifat yapılmamış ve bu çalışma herhangi başka bir akademik yayın ortamına değerlendirme için gönderilmemiştir. $\mathrm{Bu}$ araştırma doküman incelemesine dayalı olarak yapıldığından etik kurul kararı zorunluluğu bulunmamaktadır.

\section{Kaynakça}

Abrams, M. H. (1993). A glosory of literary terms. Fort Worth: Harcourt Brace Jovanovich College.

Ames, C. (1991). The modernist canon narrative: Woolfs 'Between the Acts' and Joyce's 'Oxen of the Sun'. Twentieth Century Literature, 37 (4), 390-404.

Anspaugh, K. (1994). Blasting the bombardier: another look at Lewis, Joyce, and Woolf. Twentieth Century Literature, 40, 365-78.

Baldick, C. (2001). The concise Oxford dictionary of literary terms. Oxford: Oxford UP.

Beja, M. (1971). Epiphany in the modern novel. Seattle: University of Washington Press.

Bergston, H. L. (1889). Essai sur les données immédiates de la conscience. Paris: Felix Alcan, translated in 1910 as Time and free will.

Bickerton, D. (1967). Modes of interior monologue: A formal definition. Modern Language Quarterly, 28, 229-39.

Bingshan, L. (1993). A short history of English literature. Zhengzhou, China: Henan People's Publishing House.

Booker, K. (1995). Flann O `Brien, Bakbtin, and Menippean satire. New York: Syracuse University.

Booth, W. (1961). The rhetoric of fiction. Chicago: University of Chicago Press.

Bowling, L. E. (1950). What is the stream of consciousness technique? PMLA, 65, 333-45.

Bradbury, M. (1991). Modernism: A guide to European literature, 1890-1930. Penguin.

Brontë, C. (1847). Jane Eyre. ed. by C. Bell, London: Smith, Elder, and Co., Cornhill, printed by Stewart and Murray, Old Bailey.

Buran, S. (2020, August 18). "Violence against Women in Science: The Future of Gender and Science in Gwyneth Jones's Life." Critique: Studies in Contemporary Fiction, Retrieved from https://doi.org/10.1080/00111619.2020.1803195.

Butler, C. (2004). Joyce the modernist. D. Attridge (Ed), The Cambridge Companion to James Joyce, (ss. 67- 86). UK: Cambridge University.

Carter, R. ve McRae, J. (2001). The Routledge bistory of literature in English: Britain and Ireland. London: Routledge.

Cohn, D. (1978). Transparent minds: narrative modes for presenting consciousness in fiction. UK: Princeton University.

Collins, J. (1923). The doctor looks at literature. New York: George H. Doran.

Concilio, C. (1999). Things that do speak in Elizabeth Bowen`s The Last September. W. Tigges (Ed), Moments of moment: aspects of the literary epiphany, (ss. 279-292). Netherlands: Rodopi.

Cuddon, J. A. (2013). A dictionary of literary terms and literary theory. 5th Edition, UK: Wiley-Blackwell.

De Gay, J. (2006). Virginia Woolf's novels and the literary past. Edinburgh: Edinburgh University Press.

Edel, L. (1964). The modern psychological novel. United Kingdom, Grosset \& Dunlap, 1964.

Freud, S. (1965). The interpretation of dreams. J. Strachey (Ed), NY: Avon.

Friedman, M. (1955). Stream of consciousness: A study in literary method. New Haven: Yale University Press.

Gay, P. (2008). Modernism: the lure of heresy from Baudelaire to Beckett and beyond. New York: W.W. Norton.

Gilbert, Sandra M., and Susan. Gubar. (2000). The madwoman in the attic: The woman writer and the nineteenth-century

literary imagination. Yale University Press.

Gillies, M. A. (1996). Henri Bergson and British modernism. Montréal: McGill-Queen's UP.

Heidegger, M. (1962). Being and time. J. Macquarrie and E. Robinson (Çev), New York: Harper.

Henke, S. A. (1986). Virginia Woolf reads James Joyce: the Ulysses notebook. James Joyce: The Centennial Symposium, 3942, Italy: University of Illinois Press.

Hoffmann, F. (1945). Freudianism and the literary mind. Baton Rouge: Louisiana State University Press.

Holland, G. J. (1986). George Henry Lewes and stream of consciousness: the first use of the term in English. South Atlantic review, $51,31-39$.

Holman, C. H. ve Thrall, W. F. (1985). A handbook to literature. 4th ed. Indiana: Bobbs-Merrill Education Pub.

Humphrey, R. (1954). Stream of consciousness in the modern novel. Berkeley: University of California.

James, W. (1950). The principles of psychology. New York: Dover Publications.

Jenkins, W. (1988). Virginia Woolf and the belittling of Ulysses. James Joyce Quarterly, 25 (4), 513-19.

Jin, MA. (2011). James Joyce's epiphany and Virginia Woolf's 'moment of importance'. Studies in literature and language, $2(1), 114-118$.

Joyce, J. (1922). Ulysses. London: [John Rodker, Paris, for] the Egoist Press.

Joyce, J. (1955). Stephen hero. New York: New Directions.

Joyce, J. (1964). A portrait of the artist as a young man. New York: Penguin Books. 
Joyce, J. (2008). Dubliners. Forgotten Books.

Joyce, J. (2011). The dead. United States: Melville House.

Karl, F. R. (1998). Modern and modernism: the sovereignty of the artist 1885-1925. New York: Atheneum.

Kern, S. (2011). The modernist novel: A critical introduction. UK: Cambridge University Press.

Kitson, H. D. (1921). The mind of the buyer: A psychology of selling. New York: Macmillan.

Koçsoy, G. F. (2018). Küçürek öyküde epifan. Humanitas, 6 (11), 115-127.

Kümbet, P. (2018). Psyche Unveiled: A Palpable Example of Female Gothic Genre, Ann Radcliffe's The Mysteries of Udolpho. Kocaeli Üniversitesi Sosyal Bilimler Dergisi (KOSBED), 36, 77-94

Laurence, P. O. (1991). The reading of silence: Virginia Woolf in the English tradition. California: Stanford University.

Levin, H. (1960). James Joyce. New York: New Directions.

Lillyman, W. (1971). The interior monologue in James Joyce and Otto Ludwig. Comparative Literature, 23 (1), 45-54.

Lodge, D. (1977). The modes of modern writing: metaphor, metonymy, and the typology of modern literature. Ithaca: Cornell University Press.

Lodge, D. (1992). The art of fiction. New York: Penguin Books.

Lukacs, G. (1963). The meaning of contemporary realism. J. and N. Mander (Trans. from German), London: Merlin Press.

Mahaffey, V. (2004). Joyce`s shorter works. The Cambridge companion to James Joyce, (ss. 172-198). United Kingdom: Cambridge University Press.

Moran, B. (2003). Edebiyat kuramlar ve elestiri. İstanbul: İletişim Yayınları.

Murry, J. M. (1923). The break-up of the novel. Yale Review, 12, 288-304.

Naremore, J. (1973). The world without a self: Virginia Woolf and the novel. London: Yale University Press.

Öğretir, İ. (2005). Edebiyatta epifan: Sherwood Anderson'm Winesburg Obio'su. Konya: Çizgi Kitabevi.

Parsons, D. L. (2007). Theorists of the modernist novel: James Joyce, Dorothy Richardson, Virginia Woolf. New York: Routledge.

Pearce, R. (1993). Who comes first, Joyce or Woolf. V. Neverow-Turk and M. Hussey (Eds), Virginia Woolf. themes and variations, (ss. 299-308). New York: Pace University Press.

Pugh, T. ve Johnson, M. E. (2014). Literary studies: A practical guide. New York: Routledge.

Scott, W. D. (1921). The philosophy of advertising in theory and practice: A simple exposition of the principles of psychology in their relation to successful advertising. Boston: Small, Maynard and Company.

Steinberg, E. R. (1979). The stream-of-consciousness technique in the modern novel. Port Washington, N.Y.: Kennikat.

Steinberg, E. R. (1969). The steady monologue of the interiors; the pardonable confusion . . James Joyce Quarterly, 6, 185-200.

Stevenson, R. (1992). Modernist fiction: An introduction. Lexington: U of Kentucky.

Tindall, W. Y. (1951). A reader's guide to James Joyce. New York: Farrar, Straus and Cudahy.

Verdonk, P. (2002). Stylistics. Oxford: Oxford University Press.

Whitworth, M. H. (2010). Virginia Woolf, modernism and modernity. S. Sellers (Ed), The Cambridge companion to Woolf, (ss. 107-123). UK: Cambridge University.

Woolf, V. (1919). The mark on the wall. Second Edition, Hogarth Press, Richmond.

Woolf, V. (1922). Mrs. Dalloway. New York: The Modern Library.

Woolf, V. (1937). To the lighthouse. New York: The Modern Library, Random House.

Woolf, V. (1953). The common reader; first series. Harcourt, Brace\&World.

Woolf, V. (1954). A writer's diary: being extracts from the Diary of Virginia Woolf. L. Woolf (Ed), A Harvest Book, USA: Harcourt, Inc.

Woolf, V. (1985). Moments of being. J. Schulkind (Ed), Second Edition, London: Hogarth.

Jung, C. G. (1949). Psychology of the unconscious. New York: Dodd, Mead and Company.

\section{EXTENDED ABSTRACT}

Literary modernism in the British tradition, which emerged as a revolt against the conventional novel structure and content in the early 20th century, stands out with the pioneering novelists such as James Joyce and Virginia Woolf, who use new narrative methods and techniques to emphasize the inner thoughts and feelings of the characters instead of just portraying the objective reality as it is. Departing from Ezra Pound's slogan of "Make it New!," modernist authors acquired the sacred principle of necessity by using new experimental writing techniques as the stream of consciousness (Gay, 2008, p. 106). The term stream of consciousness was first used in literature in 1918 by May Sinclair in his criticism of Dorothy Richardson's Pilgrimage (1915) (Stevenson, 1992, p. 41). Later it continued to be used and developed by authors such as James Joyce, Virginia Woolf, and William Faulkner.

Three basic philosophical ideas of the modernist period paved the way for developing the stream of consciousness: Bergsonism, pragmatism, and phenomenology. Henri Bergson's focus on the philosophy of inner experiences that life is an ongoing flow has laid the groundwork for modernist techniques that time is fluid and it does not include a chronology; therefore, the mind is also in the flow process. Psychologist and philosopher William James, in his Principles of Psychology (1890), defines the experience of consciousness as 
something continuous; "[c]onsciousness, then, does not appear to itself chopped up in bits. Such words as 'chain' or 'train' do not describe it fitly as it presents itself in the first instance. It is nothing jointed; it flows. A 'river' or a 'stream' are the metaphors by which it is most naturally described. In talking of it hereafter, let us call it the stream of thought, of consciousness, or of subjective life" (1950, p. 239). The phenomenology of Martin Heidegger deals with the philosophy of existence against the radical separation of the self and the world in Cartesian philosophy (1962, p. 149). While Heidegger focuses on the authentic and unoriginal styles of association, modernist novelists focus on the experiences of the individuals in the world they live. Sigmund Freud evaluates consciousness as a flow through the interpretation of dreams and reveals that the unconscious plays an important role in reaching our spiritual world and reality (1965, p. 632). Departing from Freud's theory of unconscious dreams, Carl Gustav Jung argues that one's own personal unconscious is influenced by the collective unconscious, including myths and archetypes from the past accumulations of the entire human race (1949, pp. 21-22). That is, in the stream of consciousness technique, as Berna Moran claims, "there is no logical connection in the thoughts that flow through the mind of the character" because "it is the darkest part of consciousness, closest to the subconscious" (2003, p. 82). In short, all those philosophies and theories lead up to new modernist narrative techniques, particularly the stream of consciousness technique (Liu, 1993).

Leon Edel sees the stream of consciousness and the interior monologue as roughly similar and argues that they can even be used interchangeably. Edouard Dujardin defines the interior monologue technique as "the speech of a character in a scene, having for its object the direct introduction of the reader into the interior life of the character, without any interventions in the way of explanations or commentary on the part of the author; like other monologues, it has theoretically no hearers and is not spoken" and claims that interior monologue is "the expression of the most intimate thoughts, those which lie nearest the unconscious" (cited in Humphrey, 1954, pp. 58-59). Robert Humphrey (1954), Wayne Booth (1961), Melvin Freidman (1955), Frederick Hoffmann (1945), and many others believe that the stream of consciousness should be determined as a literary technique that includes the inner monologue. Humphrey identifies four forms of the stream of consciousness: direct interior monologue, indirect interior monologue, omniscient description, and soliloquy (1954, 23-24). Derek Bickerton also identifies four forms of interior monologue: inner speech rendered direct speech (soliloquy), indirect speech (omniscient description), free indirect speech (indirect interior monologue), and free direct speech (direct interior monologue). Following all these arguments about modernist narrative forms and definitions, this article compares the similarities and differences in the narrative techniques of Virginia Woolf and James Joyce, who both skillfully reveal the spiritual experiences, the stream of consciousness, and inner thoughts of the characters even in a single day, going back and forth in a fluid time.

There are many studies examining the similarities between Woolf and Joyce (Jenkins 1988; Pearce 1993; Anspaugh 1994), and critics such as Christopher Ames (1991) and Jane de Gay (2006) have examined the parallels between the works of the two authors. Although Woolf and Joyce are regarded as the two most important pioneers of the stream of consciousness technique in modern English literature, there are some differences between them in terms of writing and expression techniques. Woolf's and Joyce's most obvious difference is in their style of narration; the use of the female narrative style and the male narrative style in terms of subject, perspective, sentence structure, and language, respectively. Woolf's sensitive, cyclical, and spiral female narrative and Joyce's rational, direct, linear, and cinematic narration with limited punctuation marks are some of the distinctive examples.

Woolf's moments of importance and Joyce's epiphany are the characteristic expression technique of the stream of consciousness technique in modern British fiction. Both narrative techniques aim to show moments of the stream of consciousness rather than the interpretative analysis; that is, the author does not introduce the characters, but the characters introduce themselves with their own flow of thoughts and emotions, which allows readers to develop their own imaginations and interpretations. Joyce's epiphany serves as a natural consequence of the development of the plot, and Woolf's moment of importance serves the free expansion of consciousness without any plot or logical sequence. The epiphany occurs at the sudden climax of the story that occurs at a certain time and place, and the story ends suddenly; however, the moment of importance reflects the constant flow of the character's inner world without any climax and dissolution. Joyce uses epiphany, a solution to escape from the mental dilemma, with limited punctuation, while Woolf uses moments of being, a continuous process of mental actions that do not resolve with complete punctuation. A trivial moment and an ordinary external object can be a flash of light, a sudden epiphany, or an important moment of being that help the characters dive into their own inner world, emotions, minds, 
consciousness, and thoughts. As a result, Woolf and Joyce, who have some similarities and differences in their narrative techniques, are the two most important contributors to modernist literature. 